\title{
4 The Life of Places
}

Places might seem, on the face of it, a less obvious subject for a discussion of lives. Yet as I shall try to show in what follows, places too had a changing life and a changing relationship with the people who occupied them.

What was it like to live in a Bronze Age environment? What places were home to Bronze Age people? How did they change over time, and how were they different from how they look today? These are fundamental questions to any understanding of Bronze Age life, yet complex questions to address. In what follows, I must acknowledge the influence which a number of other scholars have had on what I want to say, notably Fokke Gerritsen in his superb book Local Identities (Gerritsen 2003), Joanna Brück, and many others.

Modern archaeology recognises the complexity of the issue, but tries to find other ways around the problem. Hence the popularity of approaches that in past times would not have been considered, for instance applications that have been dubbed phenomenological - trying to experience sites and landscapes directly, for example. In this, feelings about one's surroundings include consideration not just of land (topography and vegetation) but also sound, smell and so on. Especially when we start to think about houses these are crucial aspects of experience. It is no coincidence, therefore, that some modern museum displays, or rather experiences, involve such things - the Jorvik Centre in York was one of the first to do this when it first opened in 1984 (it has since been remodelled twice). In that reconstruction of Viking York, cars travelled through the reconstructed streets and the visitor was accosted with a babble of sound as well as a range of smells, to add to the visual experience. Something similar was attempted by a team conducting survey work in southern Italy a few years ago, attempting to incorporate sound, as well as sight, into an exercise in the reconstruction of territories or catchments (Hamilton \& Whitehouse 2006).

Of course we cannot literally enter into such a past world; some cynical commentators referred to Jorvik as "heritage porn"; but in terms of fascinating the public and promoting archaeology it was a huge success. The point is that a place something like Viking York existed, but on many levels; it had a life of its own, a dynamic life, never static. It is this aspect I wish to discuss here.

\section{Space to place}

Figure 4.1 shows an example of the rock art that is popular in various parts of Europe at different times. This panel comes from the north-east of England, at

๑ OpenAccess. (c) 2021 Harding, published by De Gruyter. (cc) BY-NC-ND This work is licensed under the Creative Commons Attribution-NonCommercial-NoDerivatives 4.0 License.

https://doi.org/10.1515/9783110705805-005 
a place called Dod Law on the sandstone ridge that lies between the valley of the river Till and the Cheviot Hills and the coastal strip and North Sea (Beckensall 1974, 21; 2001, 32-36 Figs 29-36 Pl. 6; n.d. [1991?], 14-18). Another, more famous set of panels comes from the nearby site of Roughting Linn, which has been the subject of several discussions, notably by Richard Bradley (Bradley 1997, Chapter 7; the same work includes a short discussion of Dod Law, p. 123). The art is essentially undated and undatable, but these rock outcrops lie within an earthwork ring that encloses several hut circles; excavation has produced material that appears to date them to the Iron Age or Roman period, though this is far from certain (Smith 1990). These huts overlie some of the art panels, so the art probably belongs to the Bronze Age. But it is the form of the art that is so unusual, in fact unique in Britain: nowhere else does one find subrectangular or square patterns enclosing the more common simple depressions known as cupmarks. In fact, it is very plausible that what we are seeing here is a representation of local enclosures, like that surrounding the rock outcrops at Dod Law, complete with their huts, and the landscape around; in other words a map. While it has not been possible to identify the other elements or the locations represented in the "map" with any certainty, the idea remains attractive; though Ronald Morris, doyen of North British rock art studies, remarked: "I very much doubt if this is more than a coincidence", assigning the interpretation a score of 1 on his ten-point scale in a presentation of 104 possibles (Morris 1979, 25). And if this is the case, then we are looking at a rather particular way of creating a place. The transition from "space" to "place", what cultural geographers have called "inscribed spaces", is something that sociologists, anthropologists as well as geographers have often discussed (Tuan 1977; Casey 1996), and following them, archaeologists (Chapman 1988, 22-4; Tilley 1994, Chapter 1 esp. $14 \mathrm{ff}$.); here we have a form of "signing" or "inscribing" the landscape, of turning a hilltop into a known and named place (Corlett 2014; David \& Wilson 2002; Bradley 1997). This hill overlooks an extensive Neolithic landscape, containing a series of burial and ritual monuments; it lies on a moor where there are a number of Bronze Age burial mounds; and itself, as mentioned above, includes monuments of various dates. This was a place, a place that had a life, or rather several lives; a special place for those who occupied it over the centuries.

We can consider the life of places on a number of different scales; landscapes, settlement sites, houses, and engagement with places in the sense of use, and the deposition of objects. All of these are places; but I should begin by pointing out that before landscapes became "places" they were simply space. It is impossible for us to imagine pure space on this earth. It is occupied by someone or something; if not humans, then animals of various kinds. Animals have territories and therefore turn simple space into something else; we 


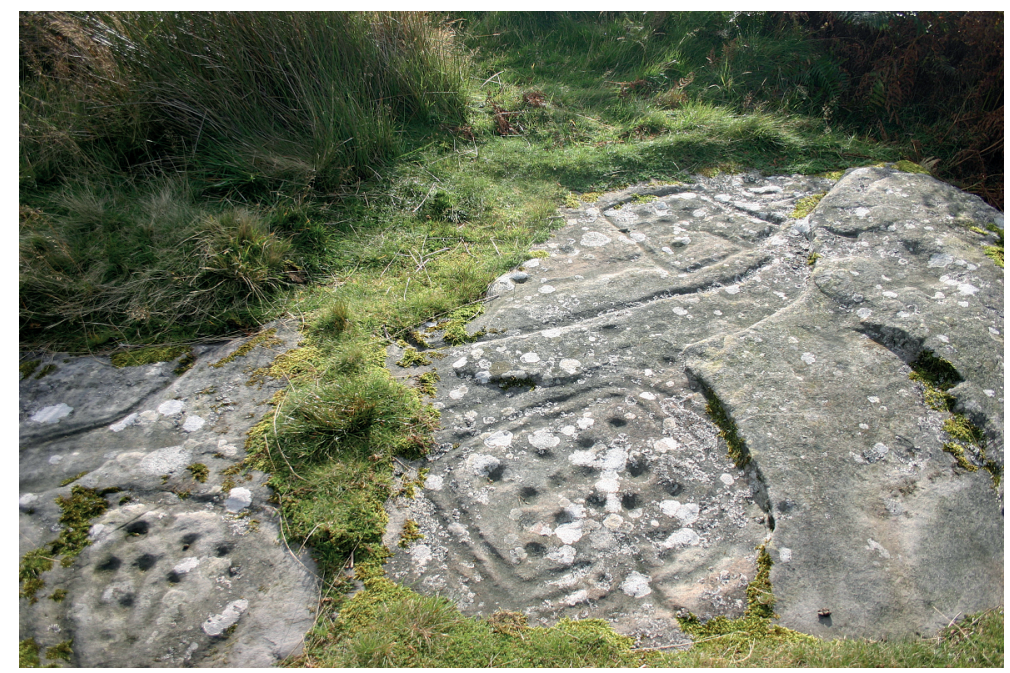

Fig. 4.1: Dod Law, Northumberland, rock art panel showing quadrilateral shapes containing cupmarks. Photo: Roger Miket, by kind permission.

are special animals but we too have territories, which we defend from aggressors; even without any humans being present pure space is formed into something else, a set of territories. When humans come on the scene, things get more complicated. There are few places on earth that can be considered genuinely wild or pristine, certainly not in the Europe we know (with the possible exception of the Białowieża Forest on the Polish/Belorussian border). But if we go far enough back, to the time when no humans were present, we can in theory chart the progression from unmarked space to space which humans marked out. "Space" has been turned into "place": people know which bit of space to visit for particular purposes, they give it a name, it becomes marked and familiar. It may simply be a natural feature, a spring, a gorge, an upstanding rock, a hilltop. But one of the ways humans create a sense of place is by creating physical marks: a cut on a tree, the removal of a group of trees to create a clearing, or in the previous instance, the engraving of specific signs or marks onto rock to create a permanent sign of presence or ownership. All these matters have been fruitfully discussed by Richard Bradley in a number of works (notably Bradley 2000; more recently Bradley 2017, esp. Chapter 3).

Anthropologists and geographers have long been interested in the relationship between space and place, and how physical space relates to social space. Eric Hirsch, for instance, discussed how these two concepts are related to several others, which represent two poles in the notion of landscape: 
foreground actuality

place

inside

image

$$
<->
$$

$<->$

$<->$

$\longleftrightarrow->$ background potentiality

space

outside

representation

Those on the left side of the diagram correspond to the context and form of everyday experience, those on the right the context and form of experience beyond the everyday, somewhat detached from what we see as we go about our lives - in Hirsch's words "perceived 'potentiality", "the way we could be”, one implication of which is that (to quote him) "sacred sites and places are sometimes physically empty or largely uninhabited, and situated at some distance from the populations for which they hold significance" (Hirsch 1995, 4).

Marking out place in this way must go back to, and perhaps beyond, the earliest humans. As life got more complicated, such creation of place got more complicated as well: not just cutting down a few trees but large areas of forest; not just creating space for economic activities, but marking cultural features as well, such as spaces for performances of various kinds. So while the place where people lived might be termed "Home", there were other places as well: "Field"; "Quarry" (for stone for axes); "River" or "Lake" where the fishing was good; and "Sacred place", where one engages in non-utilitarian activities. Here one should also introduce the concept of "place value", that is, the assigning of symbolic value to locales, as a result of continuous use, which itself derived from notions of ancestral presence and the creation of a mythology that surrounded that locale.

Others have pointed out that the move from space to place is essentially one that involves social relations: "the social properties of space are based on relations between people... a space is suitable for a function; through personal relations created to fulfil that function, the 'space' becomes a 'place"' (Chapman 1989, 33; cf McBride \& Clancy 1976), while "spatial behaviour" is an important aspect of the relationship between space and social relations (Canter 1991). It also involves identity: people identify themselves through the environment in which they move: there is a set of mental steps, from recognition to familiarity to identity.

\section{Changing places}

In this context let us take the example of a famous site, with which everyone is familiar: Stonehenge. Stonehenge is an iconic place, and recent work has shown that it had an even more complicated history than had previously been sup- 
posed; with the additional bonus that some of the quarry sites in south-west Wales for the so-called bluestones have been identified to precise location (the area has long been known as the likely source of the stones). Two of these, Craig Rhos-y-felin and Carn Goedog, have now been partially excavated and others including Carn Menyn surveyed (Parker Pearson et al. 2015; Bevins et al. 2014; Ixer \& Bevins 2011; Darvill \& Wainwright 2014; Parker Pearson et al. 2019). The Preseli Mountains, where these outcrops are situated, only rise to a maximum of $536 \mathrm{~m}$, but are windswept and inhospitable today; given the way in which the stone splits naturally to form pillar-like blocks, minimal shaping would be necessary to form what we see at Stonehenge (Fig. 4.2). It was suggested several years ago that these stones originally formed a monument, perhaps a circle, on these hills; the spot has not been found yet (if it exists), but the team say they think it must have lain between two of the outcrops and are confident they will find it (Parker Pearson et al. 2017, 5; Parker Pearson et al. 2015, 1350; Parker Pearson et al. 2019, 60). So Stonehenge apart, these Welsh hills themselves form a place with a life: perhaps a sacred place, certainly one that was of interest over many centuries (radiocarbon dates from the two excavated sites lie between 3400 and 3200 cal BC, whereas the bluestones were not erected at Stonehenge till some 300 years later).

But Stonehenge is basically a Neolithic monument in its major phases of creation, and not my concern here. It lies in the centre of an extraordinary archaeological landscape (Royal Commission on Historical Monuments 1979; Exon et al. 2000), which continues through many more centuries than merely the few hundred years that saw the digging of the ditch and the arrival of the various stones that make it seem so special. It has been known for many years that there was a significant phase of activity in the Mesolithic before construction even began (Vatcher \& Vatcher 1973) and recent work at a nearby site (Blick Mead) has added greatly to that picture (Phillips et al. 2018); in the Neolithic it lies at the heart of a major group of monuments, including the "cursus", other monuments of the so-called henge type (such as the enormous site of Durrington Walls), and a range of burial monuments of which the long barrows (mounds) are the most notable (most obviously on this map at the eastern end of the cursus) (Fig. 4.3). This was the situation in the fourth and early third millennia BC.

When we look at the same map with slightly different eyes (Fig. 4.4), we see that the Neolithic monuments are still there, but they have been supplemented with large numbers of tumuli (round mounds, usually called "barrows") (Exon et al. 2000, $76 \mathrm{ff}$., Fig. 8.1). These mostly belong to the Beaker period or Early Bronze Age, between about 2500 and 1300 cal BC. Do they have something to do with the pre-existing landscape? In themselves they have no direct connection, but 


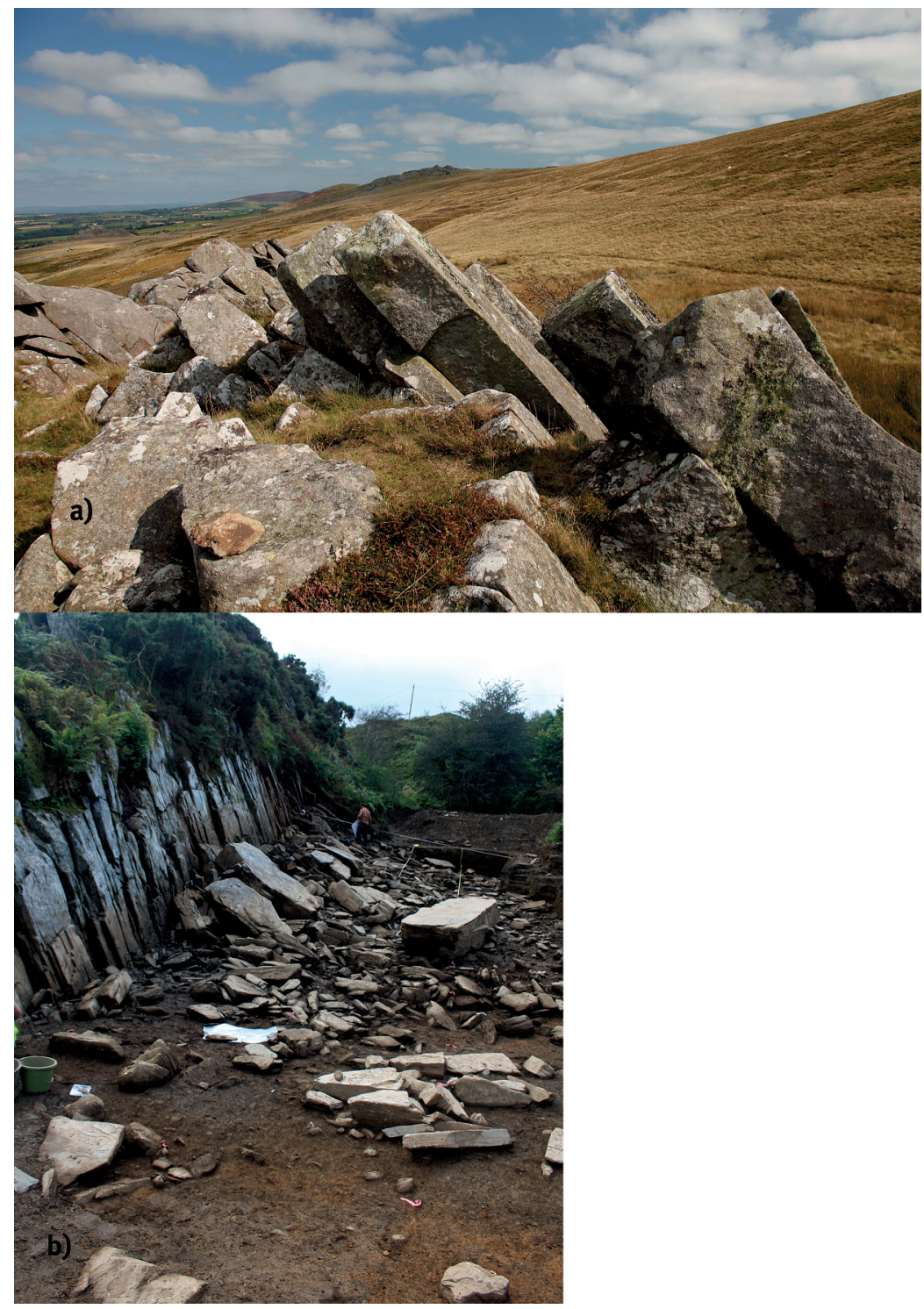

Fig. 4.2: a) Carn Goedog, and b) Craig Rhos-y-Felin, Preseli mountains, south Wales, showing the outcrops known to have been used for Stonehenge bluestones. Photos: Christine Faulkner (Carn Goedog) and Richard Bevins (Craig Rhos-y-Felin), by kind permission. 


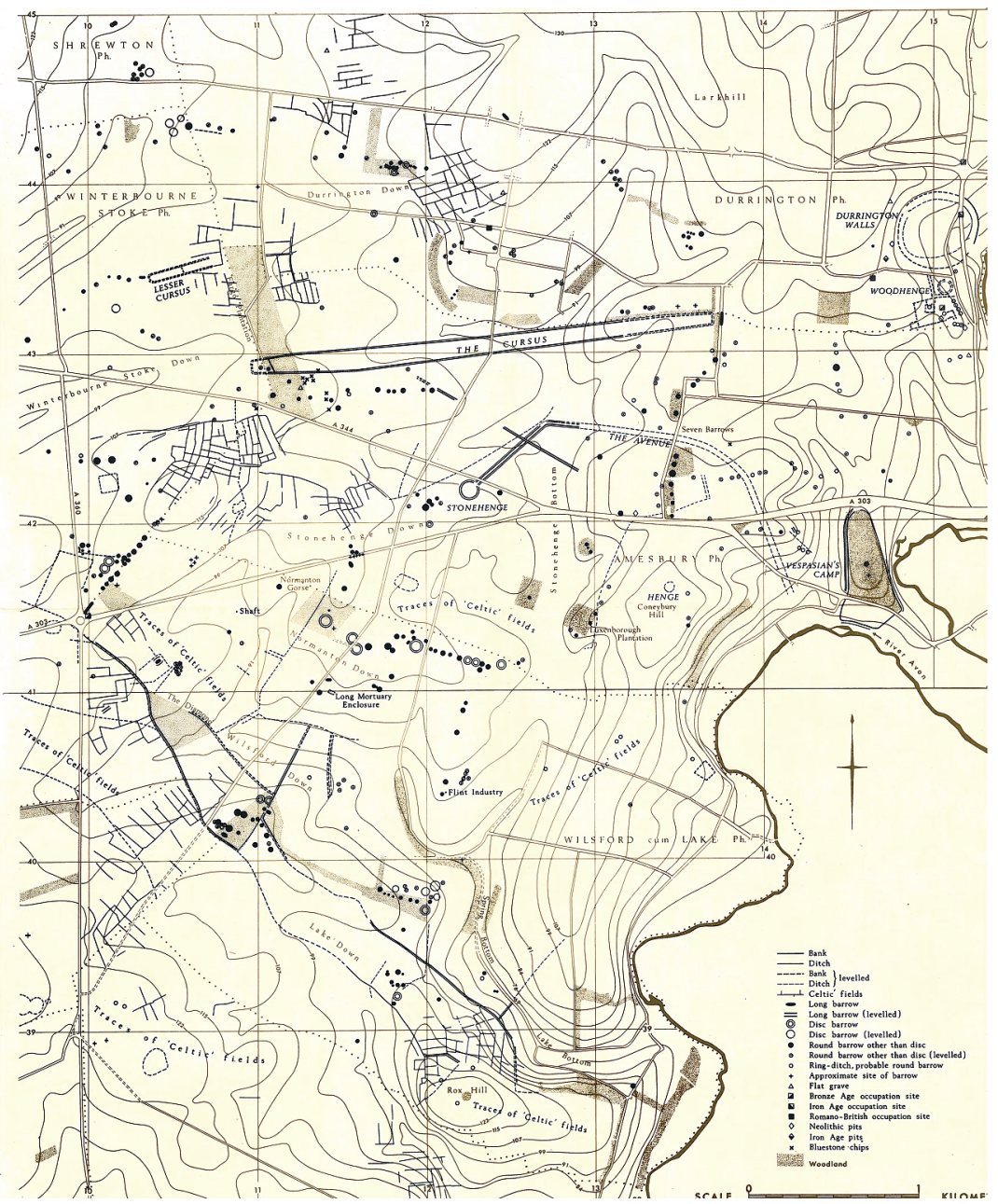

Fig. 4.3: Stonehenge environs, showing all prehistoric monuments. Source: Royal Commission on Historic Monuments 1979.

they are where they are for a reason: the area was special and had been for hundreds or even thousands of years. That is why so many important burial monuments got erected here. When we look at a close-up plan of one group of barrows, we can see that the initial focus of the burial area was a long barrow; later, round barrows got added to it to make a kind of cemetery. And one of those barrows was a famous one: Bush Barrow, excavated in the 1820s, contained what is usually interpreted as the regalia of a chief or similar important person. Bush Barrow is just one of the hundreds of such mounds erected in 
the general vicinity of Stonehenge in the Chalcolithic and Early Bronze Age, or indeed in the wider region of what in Britain is known as Wessex (after the Anglo-Saxon kingdom, the heartland of which was the modern counties of Hampshire, Wiltshire and Dorset); not that Wessex was unique in this respect, since north Germany and Denmark are just as well populated with Early Bronze Age burial mounds.

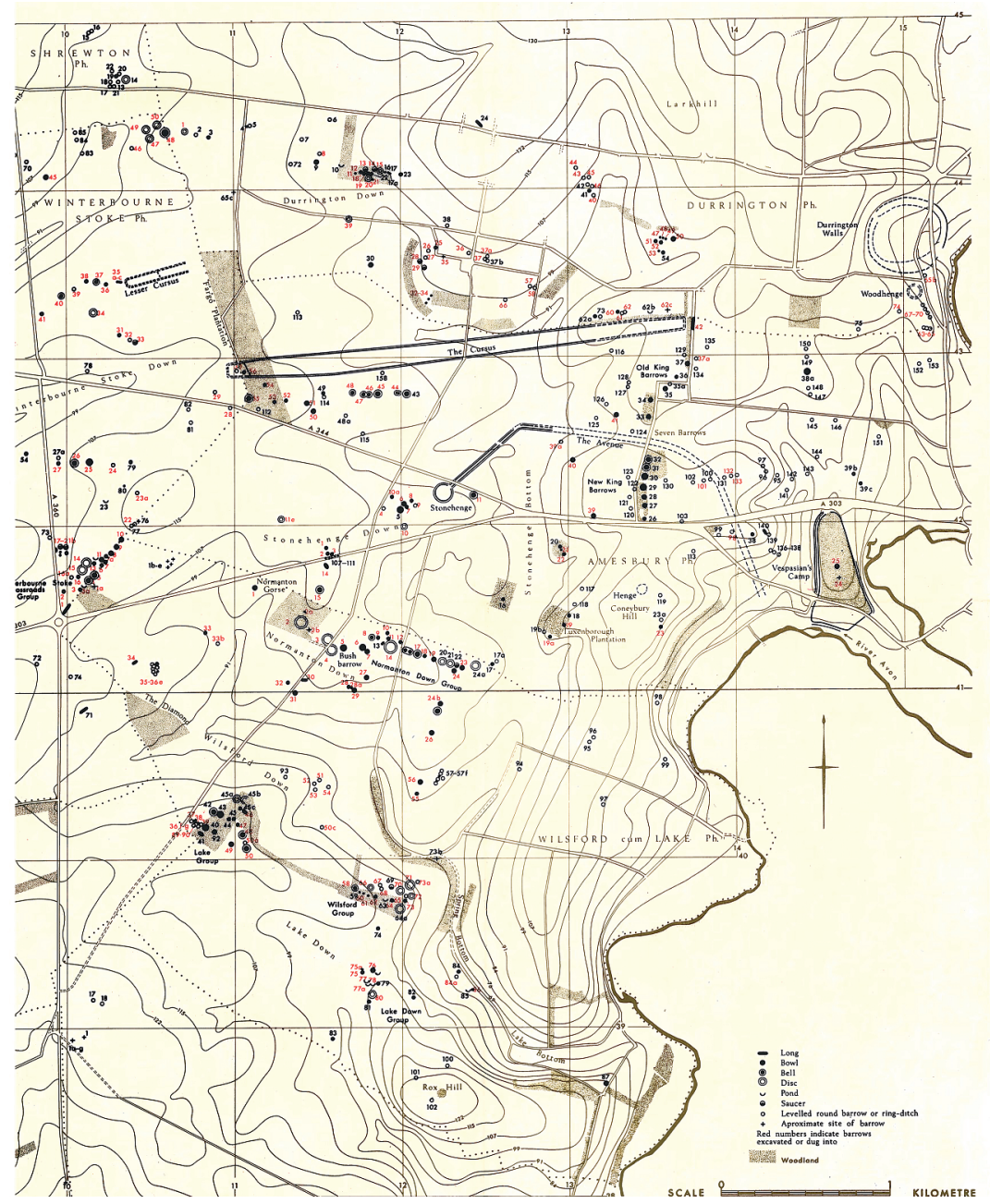

Fig. 4.4: Stonehenge environs, showing the barrows (tumuli) in the area. Source: Royal Commission on Historic Monuments 1979. 
But as well as barrows, there are other things on Fig. 4.3: fields, demarcated and detectable only by their boundaries, surviving as low banks or terraces, or, when seen from the air, as the marks left by ditches or fences. The Stonehenge area has many such groups of fields; it is by no means the richest part of Wessex in this respect, but it is fairly typical. Fields could theoretically date to almost any period of the past, and since they consist essentially of blank space it is unlikely the economic or utilised part of them could provide reliable dating evidence. In fact our study of fields is really a study of the edges of fields. Fortunately, there is enough evidence to know that many of these field systems in Wessex, like those further south-west on Dartmoor, belong to the Bronze Age, as we see from cases where there is a stratigraphical relationship (Burgess 1980, 241-2, Fig. 5.14), where fences underlie Bronze Age burial mounds (e.g. Glasbergen 1954, $64 \mathrm{ff} ., 76 \mathrm{ff}$, figs. 23, 29-30), or where the evident associations with other monuments and in some cases radiocarbon dates make a Bronze Age date plain (Yates 2007, esp. 110 -112).

Fig. 4.5 shows another part of Wessex, the Marlborough Downs, where field systems are well represented (Gingell 1992, 155-6 Fig. 96). In this example, air photography has produced a more or less complete record of land use, from which it is evident that the fields did not cover the entire area: there was plenty of land which was not so enclosed, and was probably woodland or common grazing land. There are long linear features, often called estate or ranch boundaries, cutting through the field systems and therefore postdating them; there is also a hillfort that looks to be intimately connected with the ranch boundaries. Though such sites are usually attributed to the Iron Age, in fact they frequently began life in the Bronze Age. This is another palimpsest landscape which had depth; it had a life, mirroring the life of the people who worked on it. In recent years, survey using LiDAR has also added significantly to the way in which it is possible to recognise and understand complex landscapes, in many parts of Britain and Europe.

Stonehenge itself was far from typical, so maybe the landscape around it was atypical as well. What we say about it must therefore be hedged with caveats. But this area was clearly one where a special sense of place existed. We do not know why it was originally chosen to be the centre of ritual and burial activity; we only know that there was activity on site before Stonehenge itself was built. The connection with west Wales, in the form of transporting blocks of stone weighing an estimated 2 tonnes over a distance of $220 \mathrm{~km}$ - in a straight line, much further as the travel must actually have taken place (the new work by the team excavating on the Preseli Mountains suggests a land route across to the River Severn near Gloucester - Parker Pearson et al. 2016, 1347) - shows that both areas were special, and Stonehenge very special. By 3000 cal BC, this 


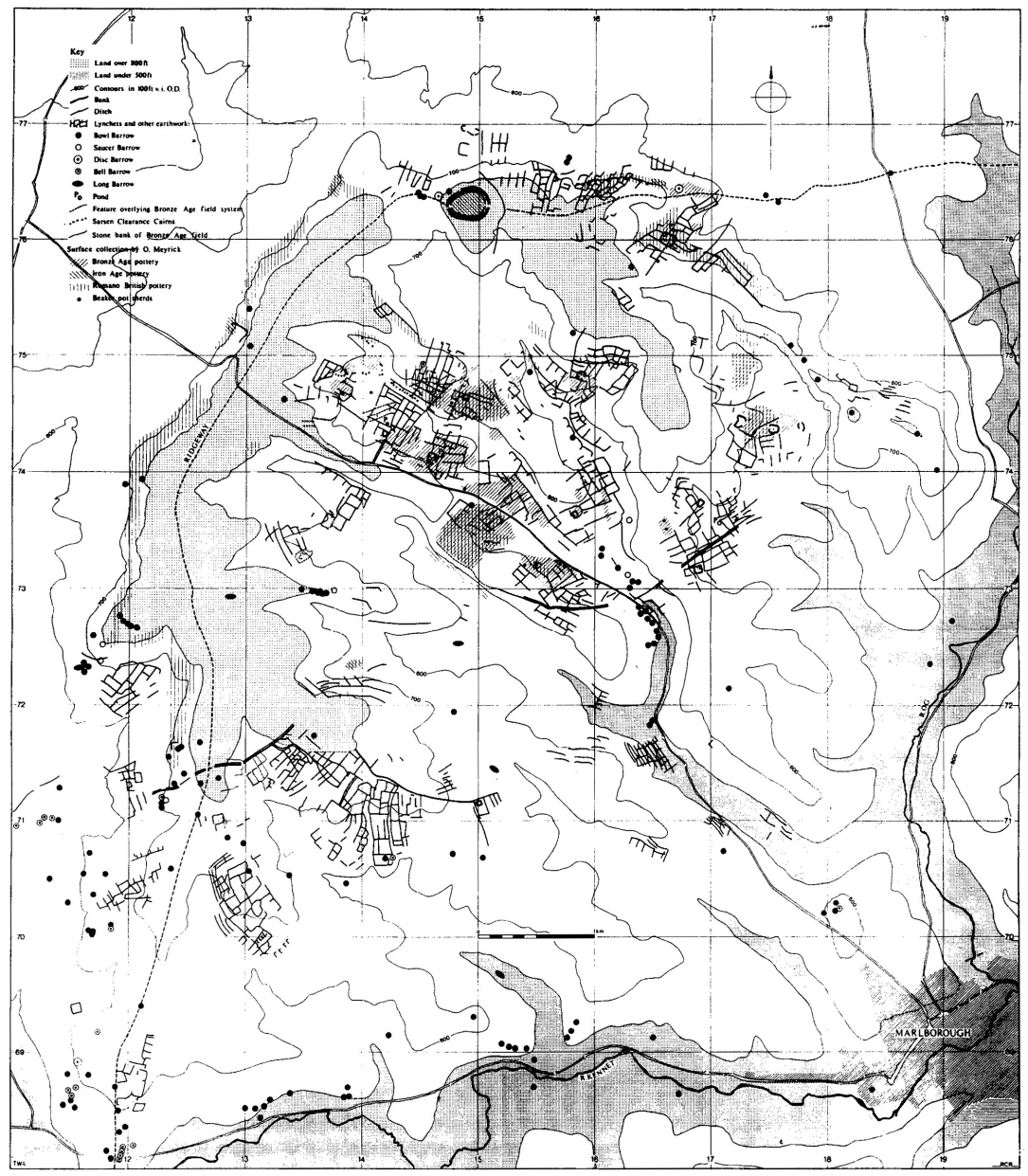

Fig. 4.5: Marlborough Downs, showing field systems, "ranch boundaries" and Barbury Castle hillfort. Source: Gingell 1992.

was a premier place in southern Britain, perhaps even over a wider area; by 2500 cal BC, it was being marked out as a prime burial place for the people who used Beaker pottery; by 1500 cal BC it was a major burial ground for rich Early Bronze Age people; but at the same time, people lived here, farmed here, and died here. This was a place with a life; and the people who lived and died here lived that life with it.

A comparable "history" of a prehistoric landscape has been charted for the Ridgeway in Oxfordshire, around the famous White Horse at Uffington (Gosden 
\& Lock 1998); the same spot was used not only for this large potentially prehistoric image, but also for burial monuments, settlements, fields, and fortified sites. Landscapes that are similarly "vivid" are present elsewhere, for instance in the Kilmartin valley in Argyll, western Scotland (RCAHMS 1988, $7 \mathrm{ff}$., $14 \mathrm{ff}$.; Ritchie \& Harman 1996, 41 ff., $135 \mathrm{ff}$.$) .$

\section{Villages and houses}

In some parts of prehistoric Europe, dwelling places - settlements - were occupied for many years, mainly but not exclusively in the Neolithic and Bronze Age. The classic example of this is the tell, as known especially from the Near East but also found in parts of Europe where conditions are right - notably Bulgaria and Hungary. Large mound sites, such as tells, were places where people continued living for many years - decades, centuries, millennia even. Here the concept of place takes on a special significance. Why do tells exist at all? After all, they are not present everywhere, even in places where they could theoretically exist. Two factors make them happen: people, in particular people's attachment to the land; and building material, to be specific mudbrick and/or daub (Chapman 1989). Without these two things, you cannot have tells. This raises the question of why people chose to stay in one place for so long; after all, at the beginning they were not tells, they were flat or terrace sites, but since house building continued year after year on the same spot, they became mounded. Within the space thus defined, houses were built and rebuilt year after year, decade after decade. Attachment to place has here become the norm: in other areas, people came and went, but here they stayed put.

\section{Village plans}

Excavations on tells have typically involved digging deep soundings through the multiple layers, cutting parts of houses but not exposing them completely. In relatively few cases in Europe complete, or near-complete, village plans are visible. Even in major excavations like at Çatal Höyük, where James Mellaart published sequences of village plans, the recent work has taken a different approach (Hodder 2014); individual houses are now well studied, especially on the upper levels of the mound. In the European Bronze Age context, work in Hungary and adjacent areas in recent years has also produced plenty of examples of house plans; the situation at Feudvar in the Vojvodina (actually on an elevated plateau) is typical, with rectangular houses succeeding one another, though not changing 
much in form and plan over the decades (Falkenstein 2014; Hänsel \& Medović 1998) (Fig. 4.6). Does this mean that the social relations between people on this site stayed the same, or just that the force of tradition conquered any desire to change the way neighbours behaved?

Here it is useful to introduce the example of a famous site of the Early Iron Age in Poland, Biskupin. Although excavation has never uncovered the entire site, from the published plans it seems fair to suppose that the whole of the fortified area was built up with long houses (Kostrzewski 1950). This has always been puzzling, in the sense that such a densely occupied site, on an island or peninsula in a lake, would seem both socially and economically unviable which is probably why the site had such a short lifetime. The same is true of at least some other sites of comparable date: for example Smuszewo, similarly densely occupied (Harding \& Rączkowski 2010) (Fig. 4.7); but there is also some variation at other closely studied sites, notably at Sobiejuchy, where there are some unbuilt areas (Fig. 4.8). I have previously suggested (Harding \& Rączkowski 2010) that this was in fact an essential for a site to survive: you need to have somewhere where people can congregate, quite apart from the need to get away from your neighbours, or your family. Could you do that on a densely settled tell site?

Recent work on Hungarian tells has focused on the nature of settlement in social terms, in particular through extensive surveys (for instance the work of Tobias Kienlin and Klára Fischl on sites in eastern Hungary (Kienlin et al. 2018) and intensive excavation projects, for instance at the site of Százhalombatta-Földvár south of Budapest (Vicze 2013; Poroszlai 2000; Poroszlai \& Vicze 2005; Vicze et al. 2014; the final report is in an advanced state of preparation). This place lies on the terrace above the Danube (Fig. 4.9), like many others along the western bank of the Danube, and while it is a deeply stratified site, its location makes it somewhat different from tell sites on the Great Hungarian Plain. The excavators have charted evidence for the building and rebuilding of houses generation after generation, noting that there is more variation in how this takes place than one might expect: there are shifts in location, and changes in the plan of individual houses. Some were erected as two-room buildings, others were apparently divided during their life (Vicze 2013); the two-room houses had a hearth in the larger room, while smaller houses may have been primarily for storage or craft activities (Fig. 4.10). Evidence for roadways between buildings, and not just paths or corridors, attest to decisions to keep houses apart from each other, and may even give us some clue into how decisions were taken, and by whom. As the excavators say (Vicze et al. 2014, 3), "The internal dynamic of minor but continuously ongoing changes brings out the sense of living communities", since people are not static and unchanging; and nor are the places where they live, at least not 


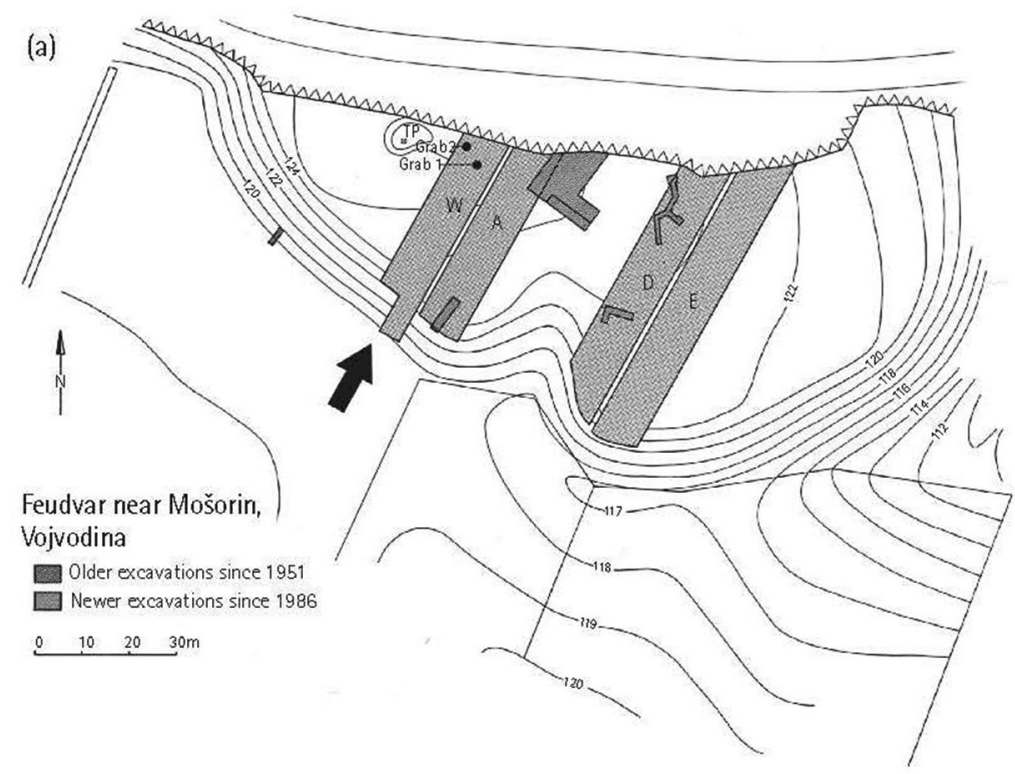

(b)
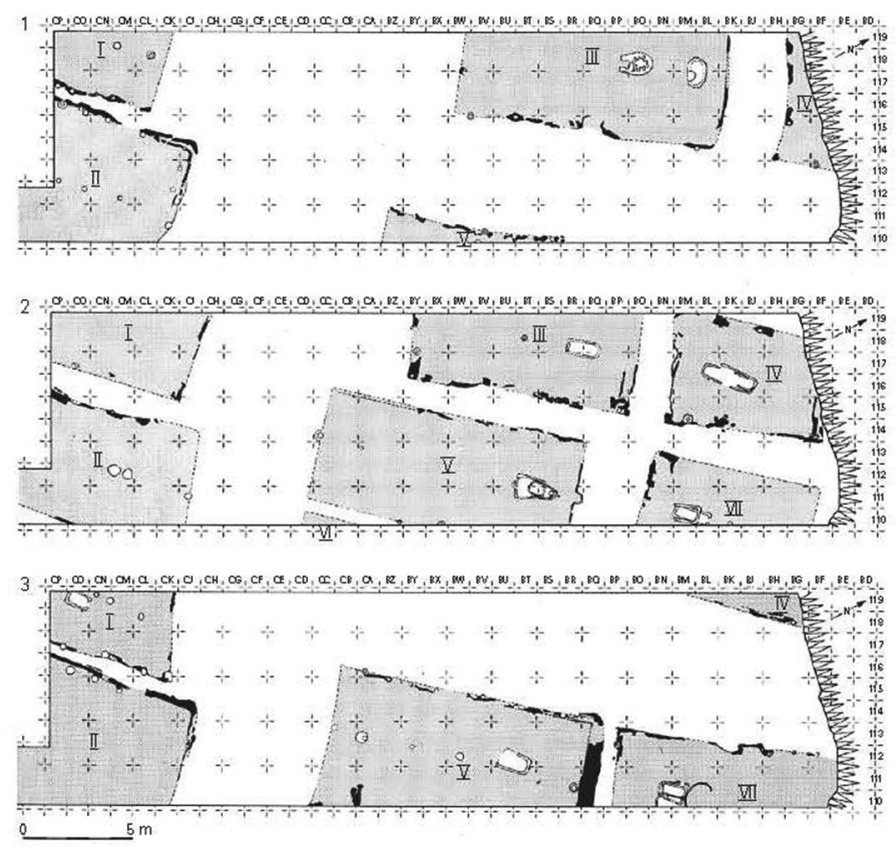

Fig. 4.6: Feudvar, Vojvodina (Serbia): plan of excavated houses. Source: Hänsel \& Medović 1998. 


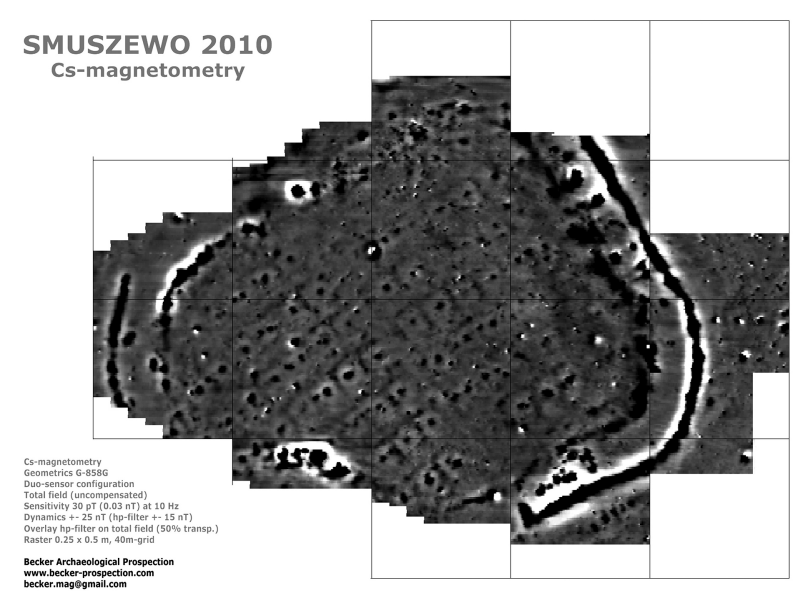

Fig. 4.7: Caesium magnetometer plot of Smuszewo, district Damastawek, Poland. Courtesy of Helmut Becker (Becker Archaeological Prospection).

when seen over a timeframe of more than a single generation. Whether house size corresponds to kin units, such as households, is also something on which we can speculate; the change over time from larger to smaller houses would then correspond to changes in how extended family units were viewed. This recalls debates in Scandinavian archaeology about the change from two-aisled to three-aisled houses during the course of the earlier Bronze Age (Bech \& Haack Olsen 2012, $14 \mathrm{ff}$. with refs). Suggestions have ranged from changing subsistence needs, such as an increased need to store foodstuffs within the house, to changing kinship organisation.

The site of Százhalombatta should not, of course, be understood in isolation. Survey work in the adjacent Benta valley has shown the existence of many other contemporaneous sites, including fortified tells like Százhalombatta (Vicze et al. 2005); this of course raises the question of how settlement in the area was organised (Earle \& Kolb 2010). More than that: the Százhalombatta tell was surrounded by a substantial ditch, in other words it was fortified, as a significant number of tells are. This means that the place we know as a tell site on the Danube has to be seen as part of a wider system of settlement, and moreover one where there was some need to consider security. There is a further point, which I owe to Tobias Kienlin: the use of space inside the fortification line is likely to be different from that outside it (Kienlin 2015, 39ff. and elsewhere). And where a plan is known primarily from geophysical survey, as for instance at Vráble-Fidvár in Slovakia (Bátora et al. 2008; Skorna et al. 2018; Bátora et al. 2012), 


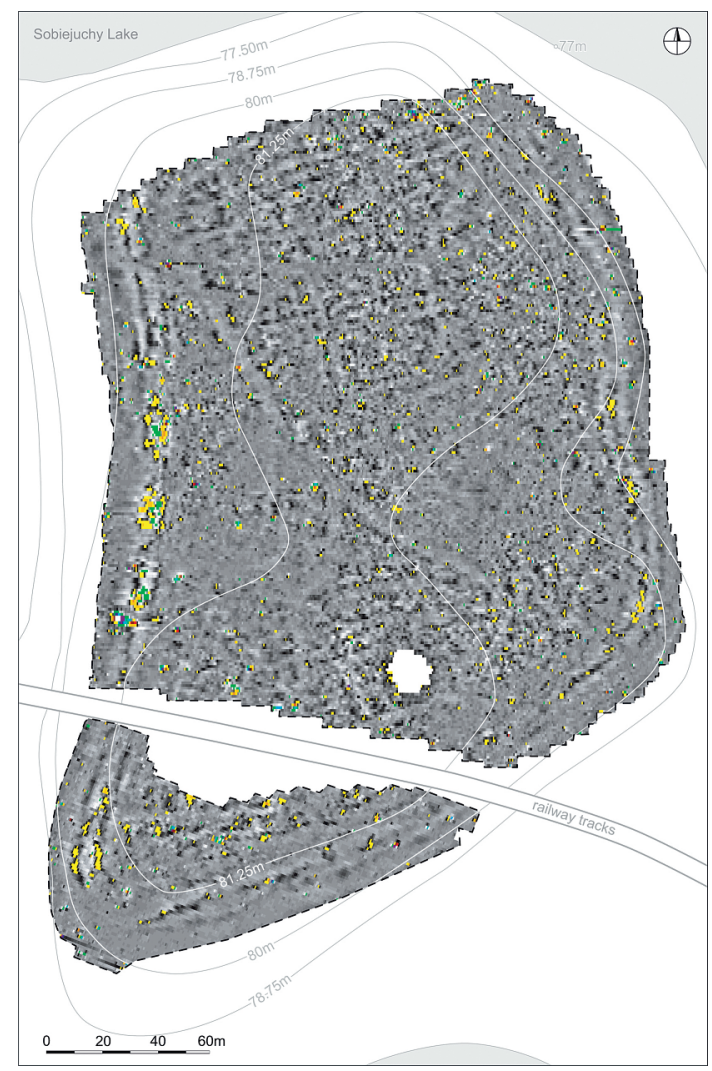

Fig. 4.8: Sobiejuchy: gradiometer plan of the site. Source: Harding \& Rączkowski 2010.

we do not know that all the houses were contemporaneous. Only detailed examination through excavation is likely to settle that point.

My next example relates to a quite different environment, but one where settlement was repeated on the same sites time after time, sometimes with a gap in occupation, sometimes with none. This concerns the numerous lake dwelling sites of the circum-Alpine region, found across all the Alpine lands but particularly well studied in Switzerland and Germany. The site of the Siedlung Forschner in the Federseemoor, for instance, has seen excavation and publication of the highest quality (Billamboz et al. 2009). The Federsee has long been known as an area where prehistoric sites, mainly Neolithic and Bronze Age, are very well preserved by virtue of the waterlogged nature of the deposits. In a Bronze Age context, the site of the Wasserburg at Bad Buchau is one of the most important (Reinerth 1928; Kimmig 1992), and would be interesting to con- 


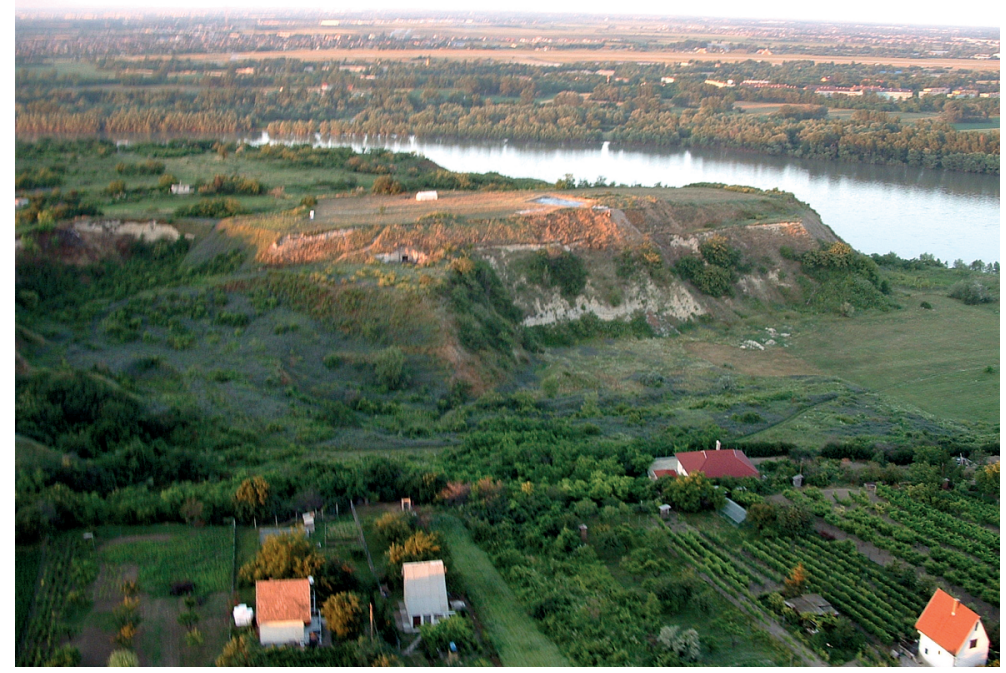

Fig. 4.9: Százhalombatta, aerial view of the site, showing its position on a terrace above the Danube. Photo and copyright Matrica Museum, by kind permission.

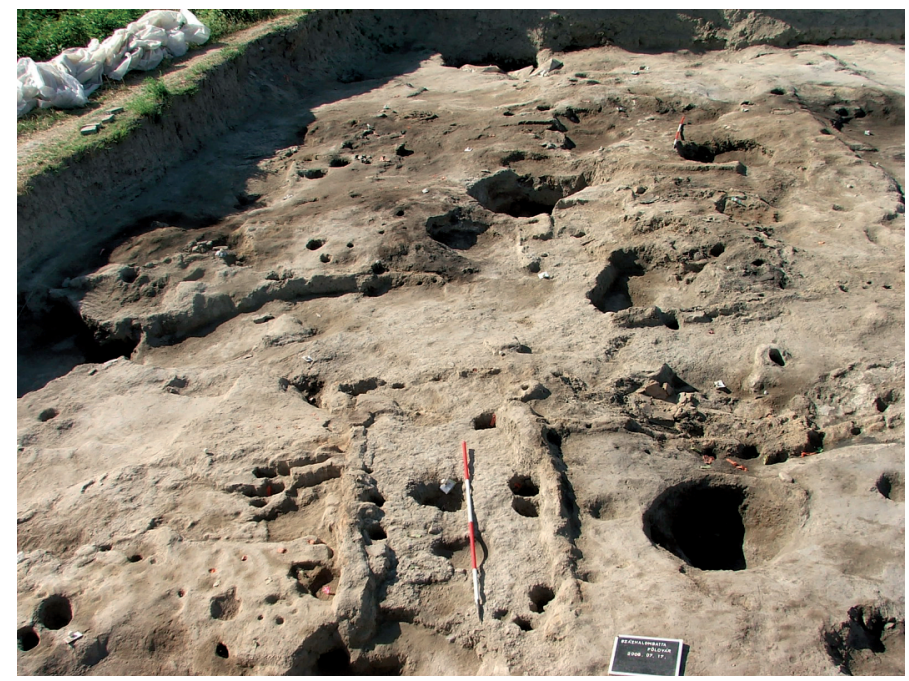

Fig. 4.10: Százhalombatta, view of two excavated houses. Photo and copyright Matrica Museum, by kind permission. 
sider in detail in the present context were it not for its unfortunate excavation history in the 1920s and 30s. The apparent change of settlement layout and house form during the Urnfield period from an earlier one with 38 small houses, the difference in size between them slight, to a later one with only nine, one of which was markedly larger than the rest, is intriguing and might be used to suggest (if the plan is to be believed) that the move reflects a social change, from a small quasi-egalitarian community to one based on power vested in major families. In practice the change may not be as great as has been thought, since the buildings of the first phase form a series of natural clusters which may represent grouped residential units or modules. The main change in the second phase is to link these units into a single building; there are several small structures interpreted as outhouses or stores. All this assumes that the plans handed down to us are correct, and that the excavator did not confuse a series of building plans of quite different dates. Kimmig's subsequent examination of the finds and pottery showed that there are in fact five identifiable phases on the site; it is not really clear which pottery phase belongs to which structures. These problems aside, the plans have obvious implications for an understanding of how people regarded the place they lived in, and how their living space should be structured within it.

When we turn to the rather earlier Forschner site (Billamboz et al. 2009), differences are again highly visible (Fig. 4.11). In this case, it is not so much that the houses change in size or shape; rather that their location varies, as does their closeness one to another. Small rectangular houses, this time built of wood, were repeatedly renewed, but always within a close-set arrangement. In this case we have the immense advantage of detailed dendrochronological evidence, which shows us the individual construction phases; and in this case it seems clear that the situation is not so different from what we saw on the Hungarian tell site - with certain important differences, of course. Sites like this, and there are many of them, provide an interesting contrast in location and building materials to what we find at the same time on tells further east; yet it is clear that people wished to remain living in the same place, even if the environment was sometimes against them (by which I mean fluctuating lake levels). These factors are hard to determine with any certainty. A recent publication suggests that it was a combination of natural and cultural factors that caused the final abandonment of the so-called lake dwellings (Menotti 2015); some Hungarian tells were also abandoned in the middle of the second millennium BC, but here it is usually cultural reasons alone that were invoked, specifically hostile incursions (this goes back to Mozsolics 1957; Bóna 1958; repeated and elaborated by Gimbutas 1965; recently reviewed by Pusztainé Fischl et al. 2013; Vicze et al. 2013). One wonders if in fact the factors I mentioned above, involving physical and social 
space, might not have been equally significant, especially as some of the lake sites, and hill sites in the hinterland, are fortified. By contrast, it has been plausibly suggested on certain Neolithic tell sites that house destruction was a deliberate act, not just for the renewal of decrepit buildings, but as a significant part of what living in a tell community involved (Stevanović 1997; Chapman 1999).

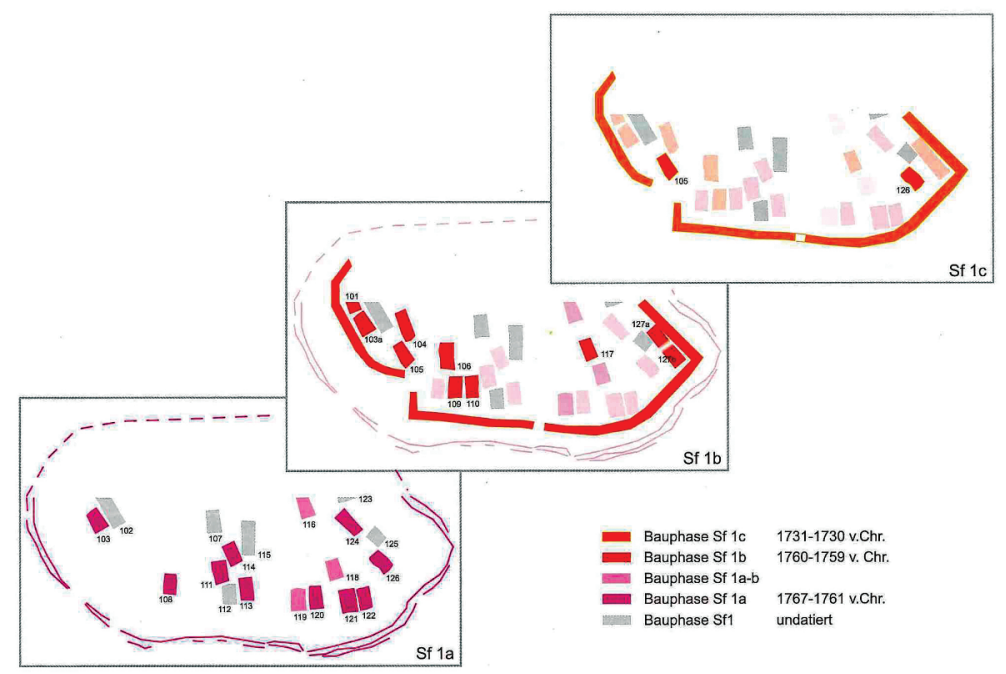

Fig. 4.11: Successive plans of the Forschner site, Federseemoor, Baden-Würrtemberg. The dendro dates show a rapidly changing layout, even within Phase 1 of the site. Source: Billamboz et al. 2009.

\section{Houses}

People live in houses, large or small; this is the space that they have made their own, where they eat, sleep, talk, are born, reproduce, and die. Nothing is so personal as this particular bit of space that we call home. They are more than just a physical presence; they represent us and our view of the world. They are a significant part of our identity, in prehistory no less than in the $21^{\text {st }}$ century, a location that serves as the centre of social practice. Gerritsen (2003) has also stressed the role of the house is creating and maintaining social identity; his hypothesis, or one of them, is that the life of a house mirrors the life of a kin group or family, perhaps even to the extent of referring to its birth and death. A similar argument was made by Joanna Brück for the Middle Bronze Age houses of southern England (Brück 1999). 
Others have stressed that the form of the house acts as a metaphor for the world view of those who lived in it, in other words what has been called the cosmology of the house. This is something that goes back to Claude Lévi-Strauss, but has been enthusiastically adopted by archaeologists in recent years (LéviStrauss 1963, Chapter 8). It is usually considered when thinking about the orientation of houses, particularly the direction in which the main entrance faces. I and many others have written that doorways would usually be placed away from the prevailing wind, for obvious reasons of comfort and practicality; this view has been criticised for ignoring the cosmological aspects of house creation. I suppose that some common ground could be found between these opposing views; certainly my view, while based almost entirely on functionality, is one that can be readily tested. I am less sure how one arrives at a commonly agreed view of the cosmological principles behind a house from three or four thousand years ago - other than through appeal to ethnography. Ian Hodder has considered Neolithic tombs from this point of view (Hodder 1994); Parker Pearson and Richards have looked at Neolithic and Iron Age houses (Parker Pearson \& Richards 1994); among many others Alistair Oswald concluded the Iron Age house orientation was determined by ritual concerns (Oswald 1997) while Avraham Faust showed that the preference for an eastern orientation of house doorways in Iron Age II Israel could not be explained just by functionality (Faust 2001). A review of the whole issue has been produced by Rachel Pope (Pope 2007).

There are plenty of Bronze Age houses in Europe, large and small, round, square or rectangular, stone, post or turf-built. Not many of them tell us a story about their lives, however. We can look at a wide range of houses, like round ones on British moorlands or on the Aeolian Islands north of Sicily, or rectangular ones from central Europe or Sicily (Fig. 4.12). But these are static, frozen in time; on their own they tell us little, though we can make estimates of how many people lived in them, and what they did there, for instance potting, weaving, leather and bone-working, storage and cooking - as Peter Drewett did for the huts in the southern English site of Black Patch (Drewett 1979; 1982). We can even estimate the length of time a given house might have stood unaltered; if wood or daub-built, probably only a maximum of 20 years, if stone-built, perhaps longer - but not much before repairs were necessary. Even in the Aegean, the stone-founded palaces of Minoan and Mycenaean Greece will surely have become rickety after a decade or two. It is a fallacy, derived from romantic notions of how everything in Greece was more advanced than elsewhere, to suppose that everything was so much better there.

So, how are we to develop ideas about the life of a Bronze Age house? One suggestion came from the Swedish scholar Inga Ullén some years ago, in connec- 


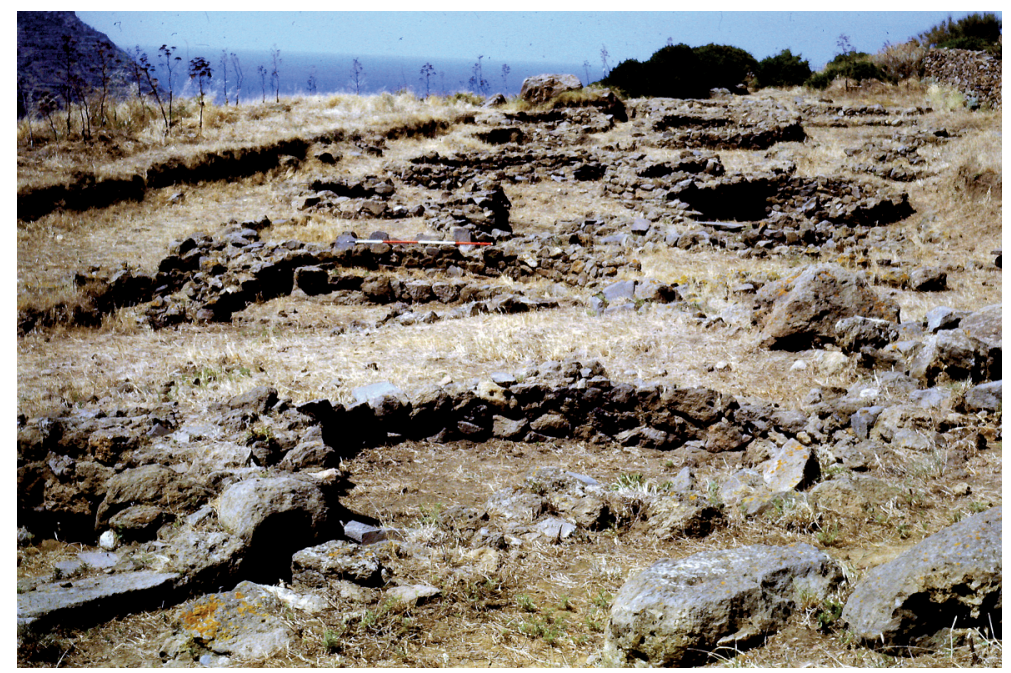

Fig. 4.12: Round houses on the Early Bronze Age settlement of Capo Graziano, Filicudi (Aeolian Islands). Photo: author.

tion with the settlement of Apalle, $50 \mathrm{~km}$ north-west of Stockholm in a small valley, the settlement area marked off by rock carvings showing ships, circles and cupmarks (the usual repertoire) (Ullén 1994). Forty-five houses are present, though not all have been analysed (Fig. 4.13). They consisted of long houses, shorter rectangular houses, and a few round houses. Parts of two heaps of fire-cracked stones were found, as well as five wells, most of them on the fringe of the site. In the south there was an unbuilt area bounded by pits. Chronologically the site is divided into five phases, but only two principal ones: an earlier one, mainly between the thirteenth and eleventh centuries BC, with eleven or twelve houses, and a younger one, mainly the ninth and eighth centuries with five or six houses. Between these two principal phases there is a transitional phase, during which the houses incorporated features of both the earlier and later settlement (I cite the author's preliminary work here, since her final report is only available in Scandinavia). ${ }^{1}$

One of the things that happened on the site was that rubbish was disposed of differently over time. To begin with, two heaps of stone were created, the houses disposed around them, with cooking pits distributed all around the site. Later,

1 I thank Inga Ullén for providing access to information on the site. 

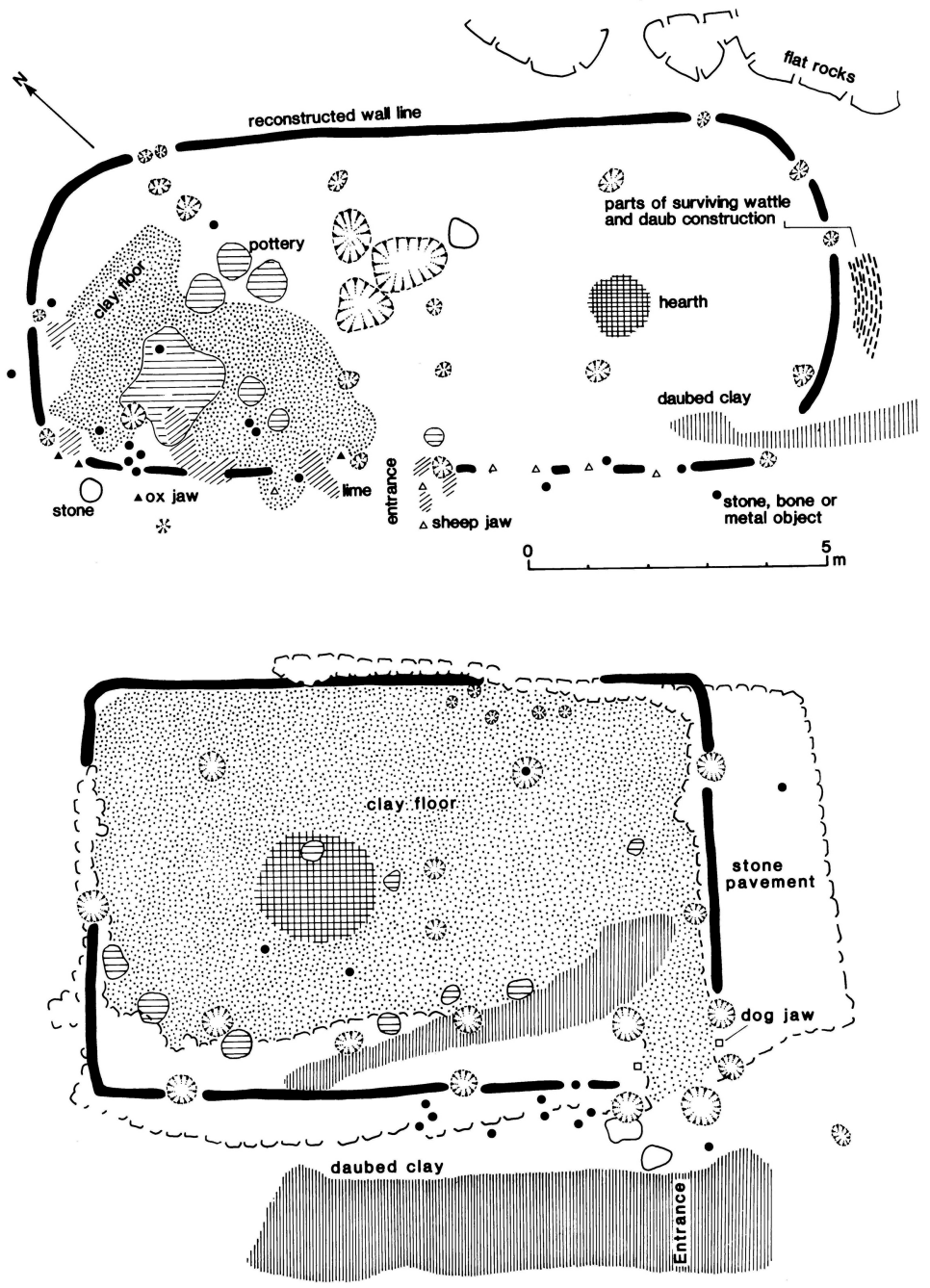

Fig. 4.13: Apalle, central Sweden. Outline plans of House 13 from the earlier settlement (upper) and House 2 from the later settlement (lower). Source: Ullen 1994.

the earlier heaps were levelled and new disposal areas created, smaller but more numerous, and all placed south of the houses, i.e. in a more peripheral location.

The rubbish heaps were structurally different as well, though that is not my main concern. Instead, it is the change in the treatment of the houses that is important. The later houses were a bit shorter than the earlier, but in both phases 
the way space was treated is interesting. The earlier houses had distinct boundaries between different rooms, in the form of post-holes for walls or rows of stones. Usually these houses were divided into two rooms. In one of the rooms there was a clay floor. This is where most of the artefacts, pottery, stone and bronze, were found, but they did not have hearths, which are in the other room. The excavator described these hearth rooms as "more anonymous", with few finds; and they could only be reached from inside the house. Their different character was further illustrated in House 13 by the occurrence of animal bones. In the notional west wall and end wall, parts of jawbones were discovered. Inside the house, as well as outside, there were only scattered bones, none of them cranial or mandibular. The mandibles were distributed in such a way that, below the entrance, towards the south-east, they were exclusively from sheep/goat. By contrast, above the entrance, in the direction of the room with the clay floor, most of the jawbones were from cattle. It was not clear whether they had been deposited in pits or laid there, next to the wall, on the outside or inside. A recognisable pit was found outside the south side of the entrance containing bones and cranial parts from sheep/goat, some of them laid out in a line. Lime was found in several of the earlier houses, in streaks along the walls and next to the roof-bearing posts in the clay-floored room. It was also found by the entrances of two houses. It was exposed towards the inside of the room and has been interpreted as traces of interior painting in this part of the house.

The interiors of the later houses looked quite different. There were no traces of lime, and only hints of room divisions. The whole of the inner room space was clay-floored and the hearth was now positioned in the centre of the house. Most of the finds occurred round the hearth. At least four houses included fire-cracked stones in the bases of the walls, perhaps a link with refuse that was now stronger than before. The piles of refuse now also included quantities of baked daub from burnt-down house walls. It seems likely that some of the fire-cracked stones incorporated in the house structure came from the heaps of stones belonging to the earlier settlement.

In addition to fire-cracked stones and daub, the later piles of refuse also included bones, mainly from domesticated animals, in contrast to the earlier houses where the stone heaps contained far more bones of wild animals. This might recall Ian Hodder's ideas about the domestication of the wild as a kind of metaphor for the whole process of domestication in the Neolithic. Later on, wild animals were ignored, or simply absent, and domestic animals became crucial. In this, the remains of dogs were very important; unlike other animals, these were never butchered and thus probably not eaten. In the earlier phase, dog bones were found in pits along the southern edge of the settlement, including several 
complete crania. But in the later phase pits containing dog bones lay close to the entrances and end walls. In two of the houses, two dog mandibles had been buried in the clay floor on either side of the entrance. To quote the excavator, "The migration of the dog from the boundary of the settlement in towards the centre (the house) can be said to symbolise an approach to the new home in the new age” (Ullén 1994, 258). She has also developed a story involving the way in which horse bones were deposited, but that lies beyond my present scope (Ullén 1996).

The excavator's interpretation of what happened is complex. The clayfloored rooms of the earlier houses, with their clear boundaries and entrances, white lime painting, and abundance of artefacts, can be regarded as both domestic and also public, whereas those with hearths are more private. Cooking apparently happened in pits outside the houses, so the hearths were probably for keeping warm. If cooking happened outside the house, the boundary between inside and outside must have been quite fluid; and if cooking happened outdoors, ideas of commensality, sharing of food with family and neighbours, come into play. In the later houses, by contrast, much of the cooking appears to have been moved indoors; there were no cooking pits outside. The hearths were deeper than before and were probably important as a central gathering point in the houses. The form of the interior also suggests that there is little or no distinction between private and public space. Rubbish disposal was also kept apart. This is taken to suggest that there was a different attitude to the treatment of space between the two phases: the house interiors might offer more openness to the outside world, but the space between houses was kept rather definite, almost private, while the attitude to rubbish also changed, so that the remains of previous generations were incorporated into the space around the settlement in a rather definite way.

Is all this an over-interpretation of what is essentially rather scanty evidence? Maybe, but it does have the merit that it treats all the archaeological finds as significant, not a matter of the chances of survival. In this there have been two (or more) schools of thought. One would follow the lines I have described here; this is the approach favoured by, among other people, Richard Bradley and his followers, who seek to interpret every find or group of finds in terms of intentional deposition resulting from a particular set of actions connected with the occupants' world view. Others would say that it is impossible to suppose that every sherd and every bone is significant in its location, given the upheavals to the terrain over the hundreds or thousands of years that have elapsed since deposition. It would appear to be impossible to prove this one way or the other, so it is up to the reader to decide which explanation is better. 


\section{The life of a house}

This brings us to a consideration in general terms of the life of a Bronze Age house. Are there any common features we can identify? Can we suppose that particular forms of building material, building style, internal features, intentional depositions, or artefact distribution have a significance that we can readily detect and interpret? Or should we just stick to so-called common sense approaches, and say that big buildings mean more people, elaborate fittings or special construction techniques are a sign of high status, and the richness (or otherwise) of artefacts found in houses are a direct reflection of those who used them and discarded them? Here I return to the work of Fokke Gerritsen, and illustrate his diagram of the life cycle or biography of a house (Gerritsen 2003, 40 Fig. 3.1) (Fig. 4.14). Starting at the top, the location is chosen, the site is prepared, and construction begins - note that this is reflected, in Gerritsen's view, by the formation of the household, in other words breeding partnerships and the birth of children. Then the family expands and so does the house; repairs are needed to keep it in good order. As the children grow up, they start to leave and the family contracts; so does the house, or rather it ceases to be maintained, and eventually has to be abandoned. After that, the location might remain special, for storage, or feasting in honour of the previous, now dead, occupants; and then the cycle starts all over again. Obviously much of this reflects modern, or least historical, experience, and is only a guide to the possibilities that house-building represents. But we can recognise in it aspects that accord with our notions of the sequence of building and replacement on many archaeological sites, even those from historical periods. Gerritsen is at pains to point out, however, that at the site level, not everything changed so dramatically; in this example the houses are renewed, but the settlement essentially remains stable.

One may compare this situation with those cases where abandonment of houses appears to have been systematic and planned, as with certain settlements in south-west England (e.g. Trethellan Farm, Cornwall: Nowakowski 1991, 208-9; 2001).

The model would seem to work well with houses on tells, and probably too with lake dwellings; it accords with what the excavators of Százhalombatta have suggested about house replacement, and one can imagine it working with the Forschner house replacements. It is impossible in most instances to say to what extent it might apply to simple round houses like those on Dartmoor, where there is little or no stratigraphy and thus phasing, and often no finds. But it can be applied to the Iron Age of north-west Europe quite satisfactorily. 


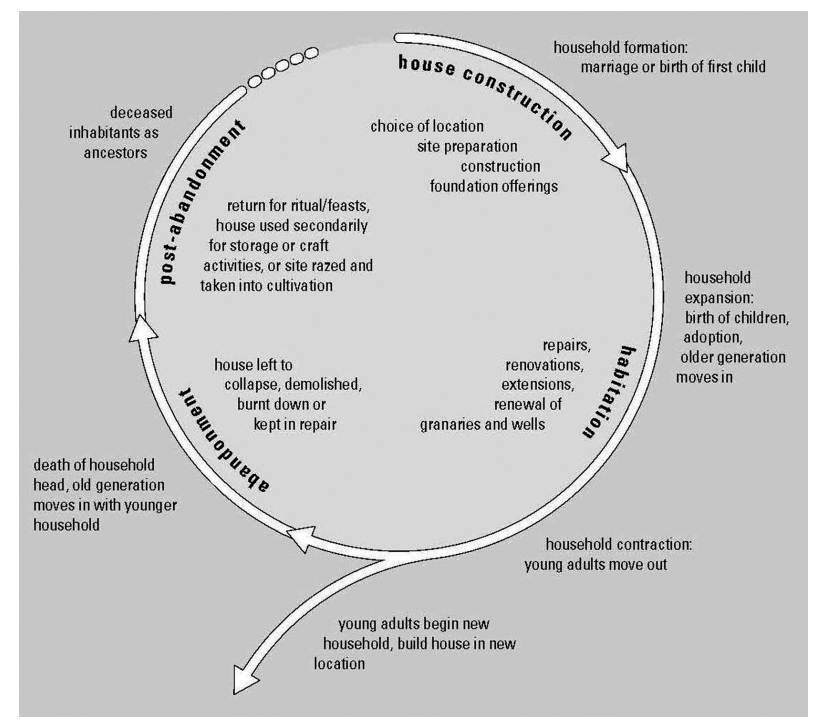

Fig. 4.14: Diagram of the putative life of a prehistoric house. Source: Gerritsen 2003.

One may recall also that on Orkney, a traditional croft house was considered dead if the fire on its hearth went out. Arrangements were made to keep the chimney smoking if the occupants were away. ${ }^{2}$ The life of a house can thus be viewed in a number of different ways.

Let me return to the point at which I started, an attempt at understanding how space became place, and how place forms an integral part of the identity of those who occupy it, indeed assigns a part of their identity to them. For the inhabitants of that hillfort in northern England, those simple huts, and that landscape view, formed a part of their identity; and one of the ways in which they marked that identity was by creating a physical map of the world around them on the rock surface, corresponding to the mental map which for them represented the world around them. This phenomenon is widespread in the Bronze Age, and probably earlier and later as well; the practice of inscribing rocks, often just with simple marks, is so common that it can only represent a form of territorial marking, apart from any symbolic value it might have had. Another example is the Iron Age and Dark Age (early medieval) hill of Traprain Law, on a volcanic outcrop some $30 \mathrm{~km}$ east of Edinburgh. Some years ago, during fieldwork to investigate the Iron Age occupation, a hoard of Late Bronze Age axes was discovered (Armit et al. 2005), and not far from it, cupmarks, i.e. rock art, on the

2 Thanks to Peter Leeming for this observation. 
bare rock (Armit \& McCartney 2005) (Fig. 4.15). The hill had been marked by previous occupants in a distinctive way. In a small way it recalls Uluru (Ayers Rock) in the middle of Australia, such a notable landscape feature, and one where natural space has been turned in a highly distinctive manner into a prime cultural feature. Across Bronze Age Europe, people were doing just that, in small ways or big ways, using rock art, using the deposition of bronzes, and using the creation of cultural spaces through the manipulation of the environment. Some of these are big and obvious, like the extraordinary art panels of Scandinavia, some are hard to spot. And some became special for many reasons, cultural and natural: in a metaphorical sense, and perhaps occasionally in a physical sense, they were where the pot of gold lay.

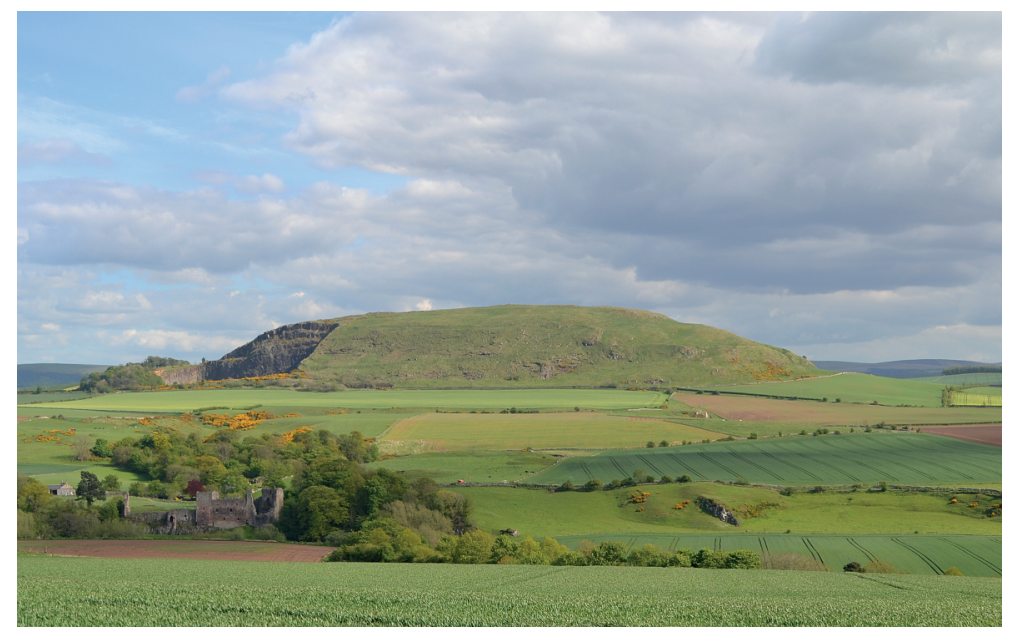

Fig. 4.15: Traprain Law, East Lothian, Scotland, viewed from the west. Photo: D.W. Harding, by kind permission. 